\title{
Expert System for Diagnosing Pregnancy Complaints by Forward Chaining
}

\author{
Embun Fajar Wati ${ }^{1)^{*}}$, Anggi Puspitasari ${ }^{2)}$ \\ 1)2) Universitas Bina Sarana Informatika, Indonesia \\ 1) embun.efw@bsi.ac.id, ${ }^{2)}$ anggi.apr@bsi.ac.id
}

\begin{abstract}
Submitted : Aug 27, 2020 | Accepted : Oct 3, 2020 | Published : Oct 3, 2020
\end{abstract}
\begin{abstract}
Limited time in consulting becomes an obstacle for midwives in diagnosing complaints in pregnant women, especially those who are already in the III trimester and approaching the labor process. Misdiagnosis results in inaccuracies in the provision of solutions and actions. Initial treatment that corresponds to the complaints of pregnant women especially the third trimester is expected to reduce mortality rates in the mother and fetus. Expert System can be a timely solution with not too long so as to improve the quality of examination on midwives. The methods used are identification, primary and secondary data collection, forward chaining data analysis combined with bayesian, and evaluation with the calculation of the percentage of system success. Samples taken by 20 patients and 4 patients were declared unsyed because they had only one complaint. Meanwhile, 16 patients had some complaints that complied with the Rules. A total of 11 out of 16 patients or about $70 \%$ had valid results between the diagnosis of experts/midwives with the system. It can be concluded that the system works well to diagnose complaints in patients with a third trimester gestational age so that midwives can provide appropriate initial solutions and treatment in reducing maternal and infant mortality.
\end{abstract}

Keywords: Diagnose; Complaints; Pregnancy; Midwife; Forward chaining

\section{INTRODUCTION}

The immortal rates of child and baby still high, one of the prolems caused by lacked of attention about healty when pregnant or improper handling when certain symptoms appear (B A Sitorus, Aris, Pribowo, \& Irawati, 2018). In addition to maintaining the growth and health of the fetus, Pregnancy care is one of the factors that need to be considered to prevent complications and death during childbirth (Widyaningsih \& Astutiningsih, 2016). The harmful effects of pregnancy risk factors for the body cannot be underestimated (Umoh \& Nyoho, 2015).

Midwives are one of the health care and screening spots for pregnant women. Besides the close distance, also at an affordable cost. But the limited hours of work practice, many patients who queued cause fatigue for pregnant women (Maryani \& Haryanto, 2018).

Many expectant mothers who conduct ULTRASOUND examinations make midwives and doctors have difficulty in diagnosing the III trimester of pregnant mothers, so that the solution given is less than optimal. It is unfortunate if the actual symptoms can be addressed early into (Munti \& Effindri, 2017).

Proper and smooth delivery process will reduce maternal mortality rate and infant. One methode to lower it is to be helped by professional health workers and perform childbirth in the health facilities (Hasbiyanor \& Bahar, 2017).

One of the methods of a system of experts diagnosing complaints in the III Trimester pregnant women is forward chaining. The Expert system (ES) aims to replace human knowledge, such as health experts, agricultural experts, etc (Hatta, Ulfah, Khairina, Hamdani, \& Maharan, 2017). Forward chaining is a method of detecting complaints or symptoms first, so it comes to a conclusion. The forward chaining method will be combined with a bayesian method that can calculate the probability percentage, so that midwives and doctors can provide the maximum solution to complaints experienced with limited practice time. This pregnancy complaint expert system will be created with Android OS. Android is a type of Operating System (OS) that makes it easy for customers who want to use (Wati, Istikharoh, \& Tuslaela, 2020). 


\section{Expert System}

\section{LITERATURE REVIEW}

An expert System is also called Knowledge Based System which is a computer application aimed at assisting decision making or problem solving in a specific field (Hayadi \& Rukun, 2016).

According to Sutojo, the benefits of Expert System in (Hayadi \& Rukun, 2016) are:

1. Increase productivity, because expert systems can work faster than humans.

2. Make a human work like an expert.

3. Improve quality by giving consistent advice and reducing errors.

4. Able to capture human expertise and knowledge.

5. Make it easy to access an expert's knowledge

6. Can be used as a supporiting media in training. Novice users who work with expert systems will become more experienced because there is a information facility that works as a teacher.

7. Improve the ability to solve problems because the expert system takes the source of knowledge from many experts.

\section{Forward Chaining}

According to Sutejo in (Hayadi \& Rukun, 2016), forward chaining is a search technique that starts with known facts, then matches those facts with the IF section of the rules IF_THEN. If there is a fact that matches the IF section, Then the ruleswill executed. When a rule is executed, a new fact (THEN section) is added to the database. Each rule should be executed onlyonce.

A rule-based model known as the forward chaining method can be seen in the following image:

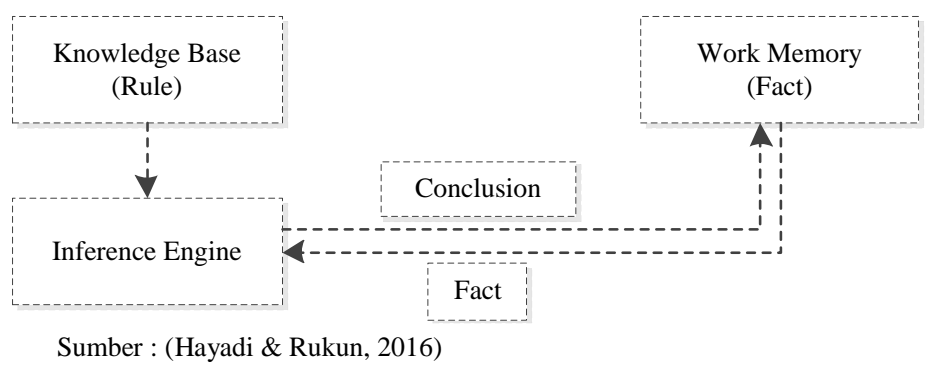

Fig. 6 Rule-Based Model

\section{Bayesian Method}

The Bayesian Method also known as the Bayesian Network (BN) is a probability graphics model that represents a set of variables and relations between these variables (Hasniati, Arianti, \& Philip, 2019). Rumus Teorema Bayes (Hasniati et al., 2019) are :

Explanation :

$$
\mathrm{P}(\mathrm{A} \mid \mathrm{B})=\frac{\mathrm{P}(\mathrm{B} \mid \mathrm{A}) \mathrm{P}(\mathrm{A})}{P(B)}
$$

$\mathrm{P}(\mathrm{A} \mathrm{B})=$ it's also calledposterior probability, which is opportunity A occurs after B.

$\mathrm{P}(\mathrm{B} \mathrm{A})=$ it's also called likelihood, which is opportunityB occurs after A.

$\mathrm{P}(\mathrm{A}) \quad=$ it is also called prior, which is opportunity A occurs

$\mathrm{P}(\mathrm{B}) \quad=$ opportunity $\mathrm{B}$ occurs.

For quality filling,the following is the terminology confidence of user's consultation which is given answer choices by each quality (Avrizal, 2019):

- Absolutely Sure : 1.0

- Very Sure : 0.8

- Sure : 0.6

- Less Sure : 0.4

- Abstain : 0.2

- Not Sure : 0

Probability is analyzed by percentage with the following possible values:

$0 \%-50 \% \quad$ Event will not occur

$51 \%-75 \% \quad$ Less event will occur 
$76 \%-84 \% \quad$ Event will occur

$86 \%-100 \% \quad$ Very Sure that event will occur

\section{A. State of Art}

This research is based on several previous studies with forward chaining methods including :

Table 1

State of Art

\begin{tabular}{|c|c|}
\hline $\begin{array}{l}\text { Title } \\
\text { Researcher, Year } \\
\text { Generate desktop-b } \\
\text { method. In this stuc }\end{array}$ & $\begin{array}{l}\text { Implementation of Expert System to Diagnose Diseases In Pregnancy } \\
\text { (Ramanda, 2015) } \\
\text { oplications with data collection for } 12 \text { diseases diagnosed using the forward chaining } \\
\text { ill be used as a reference for the diagnosis } 5 \text { symptoms. }\end{array}$ \\
\hline Title & $\begin{array}{l}\text { Web-Based Expert System Application For Pregnancy Problem Consultation Using } \\
\text { Forward Chaining And Production Rule }\end{array}$ \\
\hline Researchers, Year & (Widyaningsih \& Astutiningsih, 2016) \\
\hline \multicolumn{2}{|c|}{$\begin{array}{l}\text { To Generate web-based applications with data collection of as many as } 9 \text { diseases diagnosed using forward } \\
\text { chaining methods. In this study, it will be used as a reference for the diagnosis only } 1 \text { disease and will be used } \\
\text { the advantages of this application is the diagnosis of many questions asked by the program, so that the user only } \\
\text { selects a few symptoms listed and will be carried out a search of the nearest possibilities regarding the disease } \\
\text { suffered }\end{array}$} \\
\hline
\end{tabular}

Title Implementation of Expert System to Diagnose Diseases In Pregnancy

Researchers, Year (Afiana, Hariawan, \& Setiyadi, 2017)

To Generate a desktop-based application with data collection of 13 diseases diagnosed using qualitative forward chaining methods. In this study, it will be used as a reference to diagnosis of 2 symptoms.

Title Web-Expert System For the Detection Of Early Symptoms Of The Disorder Of Pregnancy Using A Forward Chaining And Bayesian Method

Researcher, Year (Hatta, Ulfah, Khairina, Hamdani, \& Maharan, 2017)

The results of web-based application with the logging for 11 diseases are diagnosed using forward chaining methods (FC) and BNs (bayesian methods or bayes theorems). In this study, it will be used as a reference to diagnosis for 6 diseases. The advantage of this research to be used is its method between forward chaining and bayesian method for probability of giving percent. To access the expert system, users don't need to register if they will be looking for information about pregnancy. This study also proves that abortion has a high system accuracy rate of $82.86 \%$ and eclampsia disorder of $97 \%$ by comparing the results of expert systems with the diagnosis of the doctors. The comparison between the diagnosis system and the experts will be used for students in the research of budding lecturers

$\begin{array}{ll}\text { Title } & \text { Expert System in Identifying Infectious Diseases Using Android-Based Forward } \\ \text { Chaining Method }\end{array}$

Researchers, Year (Gunawan, Defit, \& Sumijan, 2020)

To Generate android-based apps with data collection for 10 diseases diagnosed using forward chaining methods. This research has the result of a level of accuracy of the system, it obtained an accuracy rate of $90 \%$ and inaccurate $10 \%$ of the 20 test data.

The state of art table shows more accurate results: liza research with the largest probability of $97 \%$ using a comparison between system diagnosis and expert reference will used as a referency.

\section{METHOD}

The research method used as a guideline to conduct expert system research on the diagnosis of complaints in pregnant women consists of 4 stages, namely identification, logging, data analysis, and evaluation. Identification stage is the early stage in conducting research to formulate a problem by making observations. The logging phase is the stage that is done after identification and serves to obtain data from the research site or called primary data. In addition, data collection is also done to obtain data from the second source namely journals and e-books called secondary data. The third stage is the analysis of data by summarizing diseases and symptoms according to the data that has been collected from journal sources and midwife interviews. This stage also analyzes some patient complaints according to their weight obtained from the collection of primary data on patients. The last stage is an evaluation conducted by calculating the percentage of success by looking at the comparison between the results of experts / midwives and the results of expert system. An overview of the research methods can be seen below. 


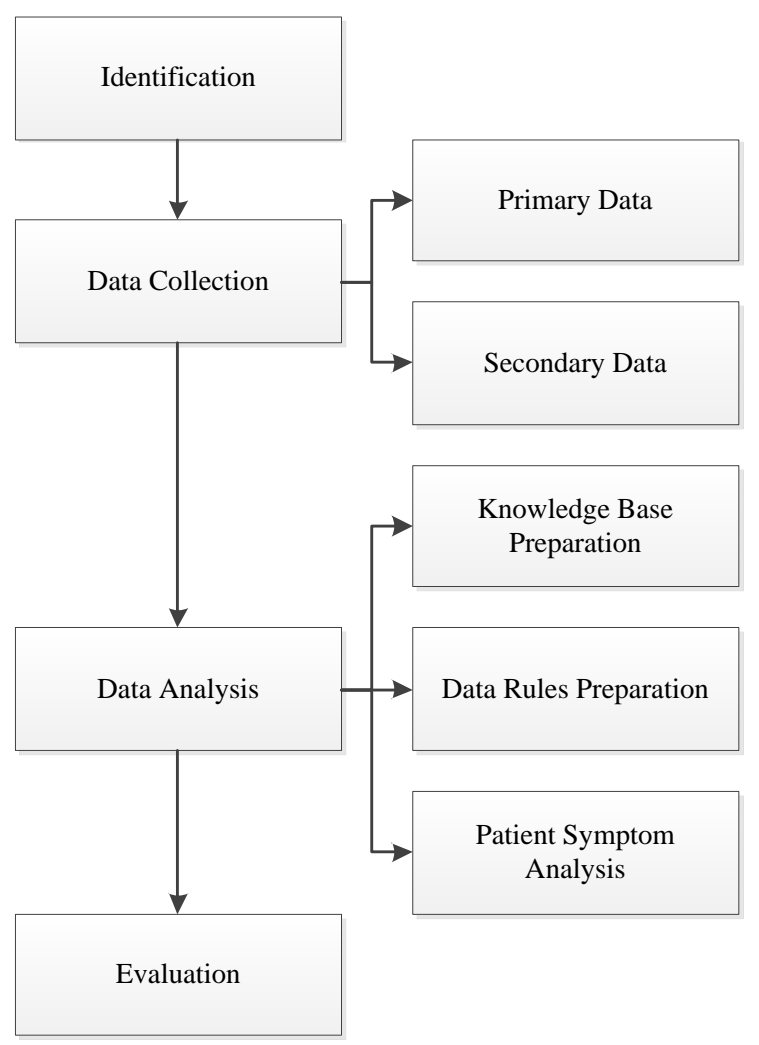

Fig. 2 Method

\section{Identification of Problems}

Identification of the problem by direct observation at the checkpoint is Midwife Rosita, by making observations on March 10, 17, and 24, 2020 and April 2 and 7, 2020 on pregnant women who come to do ultrasound examinations and. Samples were taken as many as 4 patients per day who had a gestational life of 7-9 months, up to a total of 20 patients.

\section{Data Collection}

The data sources used are :

1. Primary Data: complaint data, disease diagnosis data and solution data from interview results with midwives and pregnant women data from observation results with patients who are still conducting examinations.

2. Secondary Data: complaint data, disease data, diagnosis data and solution data taken from journals

\section{Data Analysis}

1. Knowledge Base Preparation

The knowledge base consists of disease data and symptom data which can be seen in the table below. The data from midwife interviews is a disease with codes P01, P06 and P07 as well as symptoms with codes G03, G23, and $\mathrm{G} 25$.

Table 2

Disease Data

\begin{tabular}{ccl}
\hline Source & Co & \multicolumn{1}{c}{ Disease } \\
& de & \\
\hline $\begin{array}{c}\text { (Widyaningsih \& } \\
\text { Astutiningsih, 2016) } \\
\text { (Hatta et al., 2017) }\end{array}$ & P01 & Hyperemesis third trimester \\
& P03 & $\begin{array}{l}\text { Hyperemesis gravidarum In } \\
\text { Level 1 } \\
\text { Hyperemesis gravidarum In }\end{array}$
\end{tabular}

Level 2 
P04 Hyperemesis gravidarum In Level 3

P05 Mild preeclampsia

P06 Preeklampsia

P07 Eklampsia

Table 3

Symptom Data

\begin{tabular}{ccc}
\hline Source & Code & Symptom \\
\hline (Widyaningsih \& & &
\end{tabular}

Astutiningsih, 2016)

(Ramanda, 2015)

(Widyaningsih \&

Astutiningsih, 2016)

(Ramanda, 2015)

(Hatta et al., 2017)

(Hatta et al., 2017)

(Ramanda, 2015)

(Afiana et al., 2017)

(Hatta et al., 2017)

(Hatta et al., 2017)

(Ramanda, 2015)

(Hatta et al., 2017)

(Hatta et al., 2017)

(Ramanda, 2015)

(Afiana et al., 2017)

(Hatta et al., 2017)
G01 Bleeding in young and old pregnant

G02

G03

G04

G05

G06

G07

G08

G09

G10

G11 Pulse frequency about 100 beats/minute

G12 Looks weak and limp (not fit)

G13 Yellow eyes

G14 Difficulty defecating

G15 Decreased skin elasticity

The faster the pulse frequency above 100

G16 beats/minute

G17 Small pulse as blood volume drops

G18 Increased body heat or fever

Urine slightly until it does not come out

G19 urine

G20 Vomiting and mixed blood

G21 Decreased awareness

G22 Out of sight

G23 Headache or dizziness

G24 Excess weight or greater weight gain

G25 Swollen face or other parts of the body

Blood pressure between 140/90 to

G26 160/110

G27 Proteinuria +1

G28 Proteinuria +2

G29 Proteinuria +3 or more

G30 Tensions over 160/110

G31 Heart a pain

G32 Seizures

2. Data Rules Preparation

Rule data can be seen in the following table and the decision tree can be seen in Fig. 3 .

Table 4

Data Rules 

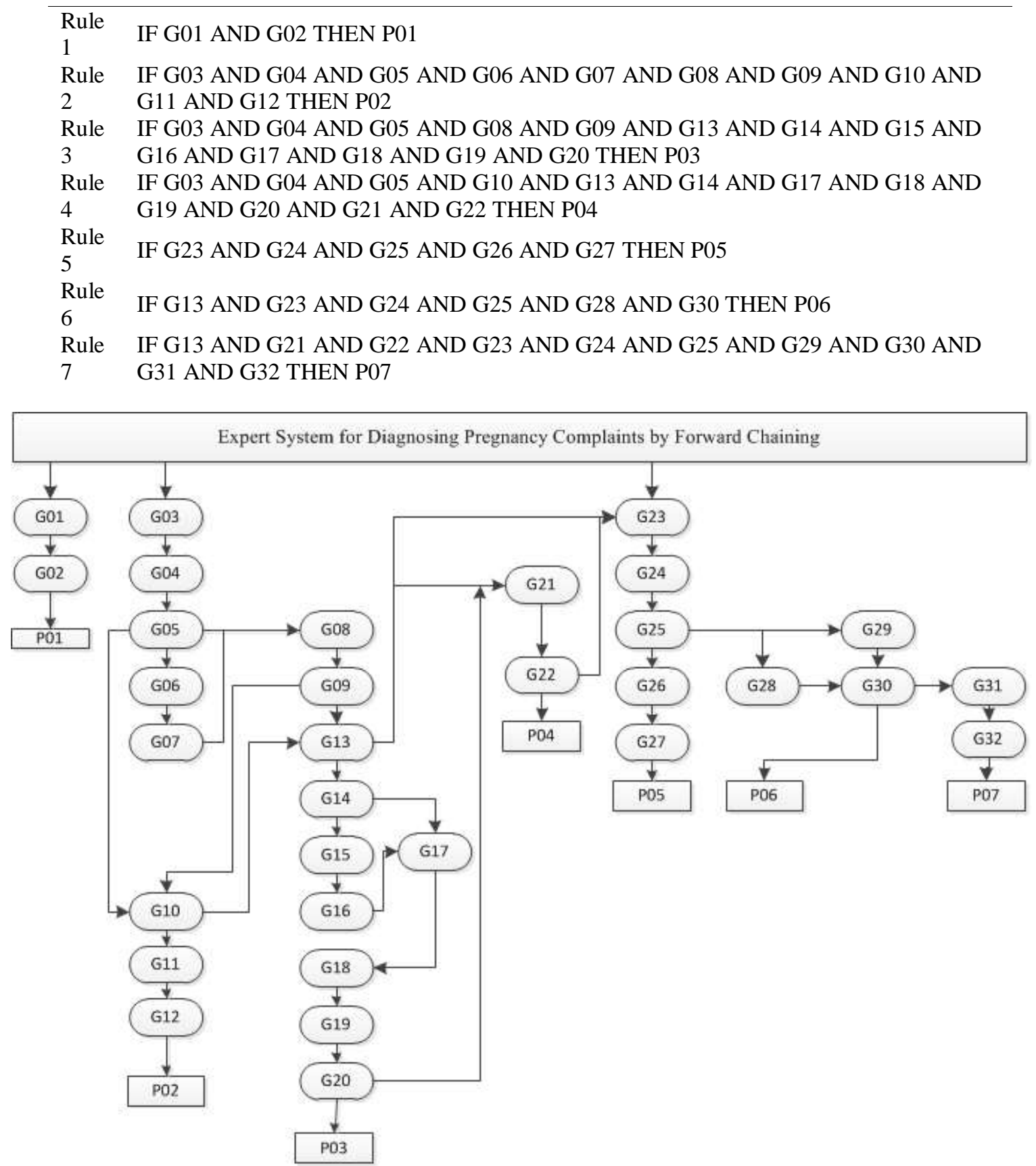

Fig. 3 Decision Tree

3. Patient Symptom Analysis

Twenty patients who have been recorded as samples, then recorded the symptoms and diagnostic results by midwives that can be seen in table 6 of the expert/midwife column. The symptoms complained of by patients were also analyzed with forward chaining and bayesian methods whose results can be seen in table VI of the system column.

\section{Evaluation}

The evaluation of the data can be seen at the conclusion.

\section{RESULT}

After consulted by testing the system on 20 patients with the age of third trimester pregnancy, the results are obtained in the table below. 
Table 5

Consultation

\begin{tabular}{|c|c|c|c|c|}
\hline Patient & $\begin{array}{c}\mathrm{Ag} \\
\mathrm{e}\end{array}$ & Symptom & Weight & Rule \\
\hline Erlita & 26 & G24 & - & - \\
\hline Sulis & 20 & G06, G23, G24, G25, G26, G31 & $1.0,0.8,0.8,0.8$ & R5 \\
\hline Dewi & 30 & G01, G02 & $1.0,0.8$ & $\mathrm{R} 1$ \\
\hline Susanti & 35 & G23, G25, G26, G27 & $1.0,1.0,1.0,0.6$ & $\mathrm{R} 5$ \\
\hline Mia & 37 & $\begin{array}{l}\text { G03, G04, G05, G06, G07, G08, G09, } \\
\text { G13, G14, G15 }\end{array}$ & $\begin{array}{l}0.4,0.8,1.0,0.6,0.8,0.6 \\
0.8,0.8\end{array}$ & $\mathrm{R} 2$ \\
\hline Cihyanti & 28 & $\mathrm{G} 23, \mathrm{G} 24, \mathrm{G} 25$ & $0.4,0.6,0.4$ & R5 \\
\hline Tri & 27 & G04, G23 & - & - \\
\hline Wiwi & 22 & G23, G24, G28, G30 & $1.0,0.8,0.4,0.6$ & R6 \\
\hline Iin & 27 & G04, G23, G24, G25, G26 & $0.6,0.6,0.6,0.6$ & $\mathrm{R} 5$ \\
\hline $\begin{array}{l}\text { Damaya } \\
\text { nti }\end{array}$ & 37 & G03, G04, G05, G07, G10, G11, G24, G26 & $1.0,0.6,0.4,0.2,0.4,1.0$ & $\mathrm{R} 2$ \\
\hline Sifa & 28 & $\begin{array}{l}\text { G04, G10, G13, G14, G15, G17, G20, } \\
\text { G21, G22, G24 }\end{array}$ & $\begin{array}{l}0.4,0.6,0.6,0.6,0.8,0.4 \\
0.8,0.4\end{array}$ & $\mathrm{R} 4$ \\
\hline Andini & 24 & G01, G03, G24, G26, G27 & $0.4,0.6,0.2$ & R5 \\
\hline Siti & 39 & G24 & - & - \\
\hline $\begin{array}{l}\text { Maharan } \\
\text { isa }\end{array}$ & 21 & G02, G04, G07, G14, G23, G24, G25, G26 & $1.0,1.0,1.0,1.0$ & R5 \\
\hline Ida & 23 & G01, G02, G03 & $1.0,1.0$ & $\mathrm{R} 1$ \\
\hline Yunita & 29 & $\mathrm{G} 24, \mathrm{G} 25, \mathrm{G} 28, \mathrm{G} 30$ & $0.6,1.0,0.6,0.2$ & R6 \\
\hline $\begin{array}{l}\text { Rika } \\
\text { Rohilia }\end{array}$ & 26 & $\mathrm{G} 25, \mathrm{G} 26, \mathrm{G} 27, \mathrm{G} 30$ & $0.6,0.8,0.4$ & R5 \\
\hline Ruqiyah & 29 & G03, G07, G13, G23, G24, G27, G28, G29 & $0.8,0.8,0.4,0.6$ & R6 \\
\hline Osti & 36 & G04 & - & - \\
\hline Dyah & 30 & G23, G24, G26, G30 & $1.0,0.6,0.4$ & R5 \\
\hline
\end{tabular}

The advantage of this system is that in terms of tracing this system does not use questions that sometimes make the user lazy to fill because it has to answer many questions asked by the program, so the user simply selects some of the symptoms that exist and the program will look for the nearest possibilities regarding the disease suffered (Widyaningsih \& Astutiningsih, 2016). Then the results on the consultation table will be selected into 16 patients, because 4 patients have only 1 complaint and do not have the potential to have the disease. In this system, it will be detected if the percentage of complaints or symptoms reaches above $60 \%$. Example of calculating the percentage of symptoms or complaints in Ida patients who have 2 symptoms that match rule 1:

$$
\begin{gathered}
\frac{\text { number of symptoms detected rule }}{\text { total symptoms rule }} * 100 \% \\
=\frac{2}{2} * 100 \%=100 \%
\end{gathered}
$$

For weight filling, the following consultation user trust terminology is given a choice of answers with each weight (Avrizal, 2019) :

Very Confident: 1.0

Sure : 0.8

Pretty sure : 0.6

A little sure: 0.4

Don't know : 0.2

Not : 0 
Probability is analyzed by percentage with the following possible values (Avrizal, 2019) :

$0 \%-50 \% \quad$ Possibility of not happening

$51 \%-75 \% \quad$ Less likely to happen

76\% - 84\% Most likely to happen

$86 \%-100 \% \quad$ Very confident it happened

Symptoms in the consultation results table with selected weights can be calculated with bayesian formula (Hatta et al., 2017) like an example in Dewi's patient.

Determination $\mathrm{P}(\mathrm{E} \mid \mathrm{Hi}-\mathrm{n})$ :

$$
\begin{aligned}
& \mathrm{P}(\mathrm{E} \mid \mathrm{H} 1)=1.0 \\
& \mathrm{P}(\mathrm{E} \mid \mathrm{H} 2)=0.8
\end{aligned}
$$

$$
\begin{aligned}
& \text { Overall weight value: } \\
& \sum_{k=1}^{10}=\mathrm{G} 01+\mathrm{G} 02 \\
& \sum_{k=1}^{10}=1.0+0.8=1.8 \\
& \mathrm{Count} \mathrm{P}(\mathrm{Hi}): \\
& \begin{array}{rl}
\mathrm{P}(\mathrm{H} 1)= & \frac{H 1}{\sum_{k=1}^{10}}=\frac{1.0}{1.8}=0.56 \\
\mathrm{P}(\mathrm{H} 2)= & \frac{H 2}{\sum_{k=1}^{10}}=\frac{0.8}{1.8}=0.44 \\
\mathrm{Next} & \mathrm{steps}: \\
& =\mathrm{P}(\mathrm{Hi}) * \mathrm{P}(\mathrm{E} \mid \mathrm{Hi}-\mathrm{n}) \\
& =\left(0.55^{*} 1.0\right)+(0.44 * 0.8) \\
& =0.56+0.352 \\
& =0.912
\end{array} \\
& \begin{aligned}
\sum_{k=1}^{n} \\
\text {. }
\end{aligned}
\end{aligned}
$$

Probability value $\mathrm{Hi}$ if given evidence $\mathrm{E}$ :

$$
\begin{aligned}
& \mathrm{P}(\mathrm{H} 1 \mid \mathrm{E})=\frac{0.55 * 1.0}{0.912}=0.61 \\
& \mathrm{P}(\mathrm{H} 2 \mid \mathrm{E})=\frac{0.44 * 0.8}{0.912}=0.39
\end{aligned}
$$

Total bayesian :

$$
\begin{gathered}
\sum_{k=1}^{10}=\text { bayesian } 1+\text { bayesian } 2 \\
=(1.0 * 0.61)+(0.8 * 0.39) \\
=0.61+0.312 \\
=0.92 * 100 \%=92 \%
\end{gathered}
$$

The results of weight calculation in other patients can be seen in the following table:

Table 6

Comparison Result

\begin{tabular}{lllcl}
\hline \multicolumn{1}{c}{ Name } & \multicolumn{1}{c}{ Expert/MidWife } & \multicolumn{1}{c}{ System } & Weight & State \\
\hline Sulis & Mild preeclampsia & Mild preeclampsia & $86 \%$ & Valid \\
Dewi & $\begin{array}{l}\text { Hyperemesis third } \\
\text { trimester }\end{array}$ & $\begin{array}{l}\text { Hyperemesis third } \\
\text { trimester }\end{array}$ & $92 \%$ & Valid \\
Susanti & Mild preeclampsia & Mild preeclampsia & $97 \%$ & Valid \\
Mia & $\begin{array}{l}\text { Hyperemesis } \\
\text { gravidarum In Level 1 }\end{array}$ & $\begin{array}{l}\text { Hyperemesis } \\
\text { gravidarum In Level 1 }\end{array}$ & $90 \%$ & Valid \\
Cihyanti & Preeklampsia & Mild preeclampsia & $51 \%$ & Invalid \\
Wiwi & Preeklampsia & Preeklampsia & $83 \%$ & Valid \\
& & & &
\end{tabular}




$\begin{array}{lllcc}\text { Iin } & \text { Preeklampsia } & \text { Mild preeclampsia } & 60 \% & \text { Invalid } \\ \text { Damayanti } & \begin{array}{l}\text { Hyperemesis } \\ \text { gravidarum In Level 1 }\end{array} & \begin{array}{l}\text { Hyperemesis } \\ \text { gravidarum In Level 1 }\end{array} & 87 \% & \text { Valid } \\ \text { Sifa } & \begin{array}{l}\text { Hyperemesis } \\ \text { gravidarum In Level 1 }\end{array} & \begin{array}{l}\text { Hyperemesis } \\ \text { gravidarum In Level 3 }\end{array} & 66 \% & \text { Invalid } \\ \text { Andini } & \text { Preeklampsia } & \text { Mild preeclampsia } & 51 \% & \text { Invalid } \\ \text { Maharanisa } & \text { Mild preeclampsia } & \text { Mild preeclampsia } & 100 \% & \text { Valid } \\ \text { Ida } & \text { Hyperemesis third } & \begin{array}{l}\text { Hyperemesis third } \\ \text { trimester }\end{array} & 100 \% & \text { Valid } \\ \text { Yunita } & \text { Primester } & \text { Preeklampsia } & 81 \% & \text { Valid } \\ \text { Rika } & \text { Preeklampsia } & \text { Mild preeclampsia } & 68 \% & \text { Invalid } \\ \text { Ruqiyah } & \text { Preeklampsia } & \text { Preeklampsia } & 77 \% & \text { Valid } \\ \text { Dyah } & \text { Mild preeclampsia } & \text { Mild preeclampsia } & 85 \% & \text { Valid }\end{array}$

After selection, 11 out of 16 patients or about $70 \%$ had valid results among experts, namely doctor diagnoda with a calculation system using forward chaining combined with bayesian. The results of the diagnosis with a bayesian calculation (\% weight) of less than $70 \%$ indicate that the results differ between the system and the expert.

\section{DISCUSSIONS}

Results showed that valid patients were about 70\%, smaller than the study (Hatta et al., 2017) which was about $82.86 \%$. This is due to the use of different bayesian methods, namely the choice of answers with each weight adopted from the terminology of the consulting user trust (Avrizal, 2019) and calculated with the bayesian formula (Hatta et al., 2017). While in the study (Hatta et al., 2017) gave direct weighting to the symptoms in the absence of a choice of answers displayed after selecting symptoms.

\section{CONCLUSION}

The conclusion that can be produced from this study is that the expert system with forward chaining method calculated by bayesian method can work quite well with valid results of about $70 \%$ or as many as 11 patients out of 16 patients who have been selected. This can be a means for midwives to see the history of complaints in patients, so as to provide appropriate initial solutions and treatment for the prevention of maternal and infant deaths in the lead up to the delivery process. For further research, it can be done the addition of symptoms and diseases, can also be done with other more up-to-date and accurate methods.

\section{ACKNOWLEDGMENT}

Thank you goes to Universitas Bina Sarana Informatika and Ristek Dikti who have given the opportunity to participate in the research of budding lecturers.

\section{REFERENCES}

Afiana, F. N., Hariawan, A., \& Setiyadi, H. (2017). Perancangan Metode Forward Chaining Untuk Mendeteksi Dini Gangguan Masa Kehamilan. In CITISEE (pp. 78-82). Purwokerto.

Avrizal, R. (2019). Sistem Pakar Mendiagnosa Penyakit Flu Babi Menerapkan Metode Hybrid Case Based. Jurnal Riset Komputer (JURIKOM), 6(2), 204-210.

B A Sitorus, Aris, Pribowo, P., \& Irawati, A. R. (2018). Expert System for Pregnant Mothers Treatment and Early Disease Detection for Infants and Toddlers Based on Android (Kasih Ibu). In ICASMI (pp. 1-6). Bandar Lampung: IOP Publishing.

Gunawan, A., Defit, S., \& Sumijan. (2020). Sistem Pakar dalam Mengidentifikasi Penyakit Kandungan Menggunakan Metode Forward Chaining Berbasis Android. Jurnal Sistem Informasi Dan Teknologi, 2(1), $15-22$.

Hasbiyanor, A., \& Bahar. (2017). Sistem Pakar Diagnosa Keluhan Selama Masa Kehamilan Menggunakan Metode Certainty Factor Berbasis Web. JUTISI, 6, 1345-1356.

Hasniati, Arianti, \& Philip, W. (2019). RAPAN METODE BAYESIAN NETWORK MODEL PADA SISTEM DIAGNOSA PENYAKIT SESAK NAFAS BAYI. Jurnal IKRA-ITH Informatika, 3(2), 19-26.

Hatta, H. R., Ulfah, F., Khairina, D. M., Hamdani, H., \& Maharan, S. (2017). Web-expert system for the detection of early symptoms of the disorder of pregnancy using a forward chaining and Bayesian method. Journal of Theoretical and Applied Information Technology, 95(11), 2589-2599.

Hayadi, B. H., \& Rukun, K. (2016). What is Expert System. Yogyakarta: Deepublish. 
Maryani, R., \& Haryanto, D. (2018). SISTEM PAKAR DIAGNOSA PENYAKIT PADA IBU HAMIL DENGAN METODE FORWARD CHAINING. JUMANTAKA, 1, 151-160.

Munti, N. Y. S., \& Effindri, F. A. (2017). Perancangan Aplikasi Sistem Pakar Diagnosa Penyakit Ginekologi Menggunakan Metode Forward Chaining Berbasis Web Mobile. Media Infotama, 13, 67-72.

Ramanda, K. (2015). PENERAPAN SISTEM PAKAR UNTUK MENDIAGNOSA PENYAKIT PADA KEHAMILAN. Jurnal Pilar Nusa Mandiri, 11(2), 179-185.

Umoh, U., \& Nyoho, E. (2015). A Fuzzy Intelligent Framework for Healthcare Diagnosis and Monitoring of Pregnancy Risk Factor in Women. Journal of Health, Medicine and Nursing, 18, 97-112.

Wati, E. F., Istikharoh, \& Tuslaela. (2020). Selection of Outstanding Lecturers with Simple Additive Weighting Method. Sinkron, 4(2), 62-67.

Wati, E. F., Siregar, M. H., \& Kurniawati, N. I. (2018). Expert System Diagnosa Penyakit Paru pada Anak dengan Metode Forward Chaining. JISICOM, 2, 10-15.

Widyaningsih, P., \& Astutiningsih, A. (2016). APLIKASI SISTEM PAKAR BERBASIS WEB UNTUK KONSULTASI MASALAH KEHAMILAN MENGGUNAKAN FORWARD CHAINING DAN PRODUCTION RULE. INFOKES, 6, 14-20. 